Ni Gusti Putu Wirawati, I Dewa Nyoman Badera, dan I. G. A. M. Asri Dwija Putri. Pengaruh Good.....300

\title{
PENGARUH GOOD GOVERNMENT, PENGENDALIAN INTERN, DAN BUDAYA TRI HITA KARANA PADA KINERJA ORGANISASI PERANGKAT DAERAH DI KABUPATEN KARANGASEM
}

\author{
Ni Gusti Putu Wirawati ${ }^{1}$ \\ I Dewa Nyoman Badera ${ }^{2}$ \\ I. G. A. M. Asri Dwija Putri
}

Fakultas Ekonomi dan Bisnis Universitas Udayana (Unud), Bali, Indonesia ${ }^{1,2,3}$ Email: ngpwirawati@yahoo.com ${ }^{1}$

\begin{abstract}
The Influence of Good Government, Internal Control, and Tri Hita Karana Culture on the Performance of Regional Apparatus Organizations in Karangasem Regency. This research aims to examine the effect of good government governance, internal control, Tri Hita Karana culture on the Performance of Regional Apparatus Organization. This research was conducted in Karangasem Regency with 96 respondents from the regional apparatus. Determination of the sample using non-probability sampling with saturation sampling technique. Data collection methods were carried out using questionnaires and data analysis technique using multiple linear regression analysis. The results of this research indicate that the variables of government governance, internal control, Tri Hita Karana culture have a positive effect on the Performance of Regional Apparatus Organization in Karangasem Regency.
\end{abstract}

Keywords: good government governance; internal control; Tri Hita Karana culture.

\begin{abstract}
Abstrak: Pengaruh Good Government, Pengendalian Intern, dan Budaya Tri Hita Karana pada Kinerja Organisasi perangkat daerah di Kabupaten Karangasem. Penelitian ini bertujuan untuk menguji pengaruh Good government governance, pengendalian intern, budaya Tri Hita Karana, pada kinerja Organisasi perangkat daerah (OPD). Penelitian ini dilakukan di Kabupaten Karangasem dengan responden sebanyak 96 orang perangkat daerah. Penentuan sampel menggunakan non probability sampling dengan teknik sampling jenuh. Metode pengumpulan data dilakukan dengan menggunakan kuesioner dan teknik analisis data menggunakan analisis regresi linear berganda. Hasil penelitian ini menunjukkan bahwa variabel Good government governance, pengendalian intern, budaya Tri Hita Karana berpengaruh positif terhadap kinerja Organisasi perangkat daerah (OPD).
\end{abstract}

Kata kunci: good government governance; pengendalian intern; budaya Tri Hita Karana. 
PENDAHULUAN

Kinerja organisasi perangkat daerah (OPD) dapat dipengaruhi oleh good government governance, pengendalian intern dan budaya organisasi dari organisasi perangkat daerah (OPD) itu sendiri. Menurut pendapat Ambarwati dkk, (2013) menyatakan bahwa organisasi yang menerapkan praktek good government governance (GGG) telah berupaya meminimalkan risiko keputusan yang salah atau yang menguntungkan diri sendiri, sehingga meningkatkan kinerja pemerintahan. Sehingga dapat memajukan pemerintahan Kabupaten Karangasem.

Good government governance akan tercapai apabila prinsip-prinsipgood government governance dapat terlaksana dengan baik. Penelitian tentang good government governance memberikan bukti empiris bahwa variabel good government governance merupakan faktor penting yang berpengaruh terhadap kinerja organisasi perangkat daerah (OPD) (Setyawan \& Putri, 2013). Hal lain yang mempengaruhi kinerja organisasi perangkat daerah (OPD) adalah pengendalian intern akuntansi. Dengan pengendalian intern yang baik maka pemerintah akan dapat menghasilkan laporan keuangan yang berkualitas.
Budaya juga menjadi faktor penting yang berpengaruh pada kinerja OPD. Tri hita karana dapat memberikan panduan bagaimana manusia harus bersikap terhadap tiga hal; hubungan manusia dengan Tuhan Yang Maha Esa (parahyangan), hubungan manusia dengan manusia (pawongan), dan hubungan manusia dengan lingkungan (palemahan) agar manusia dapat mencapai kesejahteraan berkelanjutan (Agung, 2004).

Tujuan dari penelitian ini adalah untuk mengetahui pengaruh penerapan good government governance, pengendalian interen, dan budaya tri hita karana terhadap kinerja organisasi perangkat daerah (OPD). Penelitian ini diharapkan dapat memberikan wawasan mengenai teori keagenan dan teori stewardship dalam menjelaskan pengaruh good government governance, pengendalian intern, budaya tri hita karana terhadap kinerja kinerja organisasi perangkat daerah (OPD). Selain itu juga diharapkan penelitian ini dapat menjadi referensi bagi penelitian selanjutnya dan dapat memberikan sumbangsih pemikiran terhadap peningkatan kinerja kinerja organisasi perangkat daerah (OPD).

Berdasarkan landasan teori dan kajian 
empiris dari penelitian sebelumnya, maka Hasil penelitian tersebut menunjukan bahwa kerangka konseptual yang digunakan dalam prinsip-prinsip good government governance penelitian ini dapat dilihat pada gambar berikut. yang diproksikan dengan akuntabilitas,

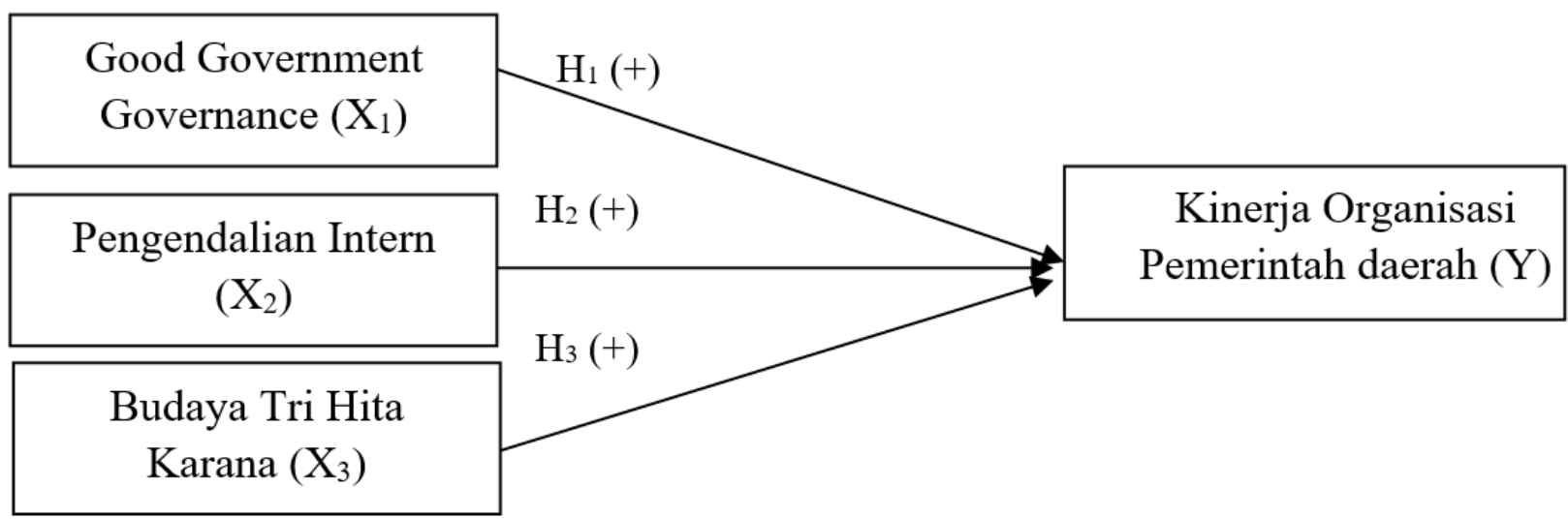

\section{Gambar 1. \\ Kerangka Konseptual}

Good government governance diartikan transparansi, partisipasi, kemandirian, dan sebagai tata kelola pemerintahan yang baik pertanggungjawaban berpengaruh positif pada suatu organisasi yang dilandasi oleh etika terhadap kinerja pegawai. Berdasarkan profesional dalam berkerja atau berkarya. uraian dan hasil penelitian sebelumnya, maka Di era sekarang ini banyak masyarakat yang hipotesis yang diajukan adalah:

sudah pandai dalam menilai kinerja aparatur H1 : Good government governance pemerintahan, masyarakat meminta semua berpengaruh positif terhadap kinerja kinerja aparatur pemerintahan benar- organisasi perangkat daerah (OPD) di benar dilakukan secara transparan dan Kabupaten Karangasem.

bertanggungjawab sehingga meningkatkan Pengendalian intern merupakan suatu kinerja aparatur pemerintahan. Hal tersebut proses yang dipengaruhi untuk memberikan sejalan dengan penelitian Fauziah (2016) jaminan yang meyakinkan bahwa tujuan analisis pengaruh prinsip-prinsip good organisasi dapat dicapai melalui : efisiensi government governance terhadap kinerja dan efektivitas operasi, penyajian laporan aparatur pemerintah(studi empiris padasatuan keuangan yang dapat dipercaya, ketaatan kerja perangkat daerah Kota Surakarta). terhadap undang-undang dan aturan yang 
berlaku (COSO). Nurillah \& Muid (2014) membuktikan secara empiris bahwa sistem pengendalian internal memiliki pengaruh signifikan terhadap kualitas laporan keuangan pemerintah daerah. Hal ini didukung oleh penelitian yang dilakukan oleh Sugandi dkk., (2014) bahwa sistem pengendalian internal memiliki pengaruh signifikan terhadap keterandalan laporan keuangan pemerintah daerah. Penelitian Yosefrinaldi (2013) menemukan hasil bahwa sistem pengendalian intern pemerintah berpengaruh positif terhadap kualitas laporan keuangan pemerintah daerah. Berdasarkan uraian dan hasil penelitian sebelumnya, maka hipotesis yang diajukan adalah:

$\mathrm{H} 2$ : Pengendalian intern berpengaruh positif terhadap kinerja Organisasi perangkat daerah (OPD) di Kabupaten Karangasem.

Tri hita karana dapat dikatakan sebagai suatu budaya, konsep ini dianut dan menjadi dasar kehidupan dalam masyarakat Bali. Nilai yang terkandung dalam Tri hita karana ini mengajarkan manusia selalu menjaga keselarasan dan keharmonisan hubungan antara manusia dengan manusia, antara manusia dan alam/lingkungan, serta antara manusia dengan yang di atas (Tuhan). Robbins (2010:64) menyatakan bahwa kekuatan budaya akan menghasilkan kinerja organisasi yang baik, karena dianggap bahwa budaya yang kuat adalah budaya yang menanamkan nilai-nilai utama secara kokoh dan diterima secara luas. Maka dapat diajukan hipotesis berikut.

H3: Budaya tri hita karana berpengaruh positif terhadap kinerja organisasi pemerintahan daerah (OPD) di Kabupaten Karangasem.

\section{METODE PENELITIAN}

Penelitian ini dilakukan pada operasional perangkat daerah (OPD) Kabupaten Karangasem. Populasi dalam penelitian ini adalah pegawai bagian keuangan di organisasi perangkat daerah Kabupaten Karangasem. Metode penentuan sampel yang digunakan dalam penelitian ini adalah teknik sampling jenuh. Oleh sebab itu penelitian ini mengambil jumlah sampel sebanyak 3 (tiga) pegawai. Adapun yang menjadi kriteria responden dalam penelitian adalah kepala bagian keuangan dan dua staf pegawai bagian keuanganyang bekerja pada organisasi perangkat daerah (OPD) Kabupaten Karangasem. 
Penelitian ini pertama kali dilakukan Perangkat daerah dibentuk berdasarkan tahap uji validitas dan uji reliabilitas terhadap pertimbangan karakteristik, potensi, kebutuhan kuesioner. Selanjutnya akan dilakukan uji daerah. Organisasi perangkat daerah (OPD) asumsi klasik dan teknik analisi data. Teknik Kabupaten Karangasem ditetapkan dengan analisis data yang digunakan dalam penelitian Peraturan Daerah Kabupaten Karangasem ini adalah analisis regresi linear berganda, dengan berpedoman pada Peraturan Pemerintah. karena terdiri lebih dari dua variabel independen. Pemerintah Kabupaten Karangasem memiliki Adapun rumus persamaan dari regresi linear 32 organisasi perangkat daerah yang memiliki berganda yang digunakan dalam penelitian ini tugas dan fungsi masing-masing dalam adalah sebagai berikut penyelenggaraan pemerintahan di Kabupaten $\mathrm{Y}=\alpha+\beta_{1} \mathrm{X}_{1}+\beta_{2} \mathrm{X}_{2}+\beta_{3} \mathrm{X}_{3}+\varepsilon$
Keterangan:

$\mathrm{Y} \quad=$ kinerja Organisasi perangkat daerah

$\alpha \quad=$ konstanta

$\beta_{1}-\beta_{3}=$ koefisien regresi

$\mathrm{X}_{1}=$ Good government governance

$\mathrm{X}_{2} \quad$ pengendalian intern

$\mathrm{X}_{3} \quad$ = budaya Tri Hita Karana

$\varepsilon \quad=$ error

\section{HASIL DAN PEMBAHASAN}

Organisasi perangkat daerah (OPD)
Karangasem, diantaranya membantu penyususnan kebijkan dan koordinasi, pengawasan, perencanaan, pelaksanaan kebijakan yang bersifat spesifik, pelaksana urusan otonomi daerah, penyelenggara sarana dan pelayanan kesehatan, serta pelaksana kebijakan dalam bidang ekonomi dan pembangunan.

Uji validitas digunakan untuk mengukur sah atau valid tidaknya suatu kuesioner. Ghozali (2016:53) mengatakan suatu instrumen akan dikatakan valid apabila nilai $\mathrm{r}$ Kabupaten Karangasem adalah perangkat pearson correlation terhadap skor total diatas daerah merupakan organisasi atau lembaga $0,3(\mathrm{r} \geq 0,3)$. Hasil $r$ perason correlation untuk pada pemerintaha daerah yang bertanggung variabel good government governance sebesar jawab kepada kepala daerah dalam rangka 0,491-0,842, variabel pengendalian intern penyelenggaraan pemerintahan di daerah. sebesar 0,834-0,925, variabel budaya Tri Hita 
Karana sebesar 0,683-0,769 dan variabel kinerja manajerial sebesar 0,791-0,929. Hasil tersebut menunjukkan nilai $r$ pearson correlation yang lebih besar dari 0,30 sehingga keempat variabel dalam kuesioner tersebut dinyatakan valid.

Pengujian reliabilitas dilakukan untuk mengukur sebuah kuesioner yang merupakan indikator dari variabel atau konstruk. Suatu kuesioner dikatakan reliabel apabila jawaban responden terhadap pernyataan adalah konsisten dari waktu ke waktu (Ghozali, 2013:47). Uji ini dilakukan terhadap instrumen dengan koefisien Cronbach's Alpha. Apabila nilai koefisiennya lebih besar dari 0,70 maka instrumen yang digunakan reliabel. Hasil menunjukkan bahwa nilai cronbach's alpha masing-masing variabel memiliki nilai lebih besar dari 0,70, sehingga pernyataan dalam kuesioner penelitian dinyatakan reliabel.

Uji normalitas bertujuan untuk mengetahui apakah masing-masing variabel terikat dan variabel bebas atau keduanya mempunyai distribusi normal atau tidak. Hasil dari uji normalitas menunjukkan bahwa nilai signifikansi Asymp. Sig. (2-tailed) sebesar 0,149 $(0,149>0,05)$ bahwa model regresi berdistribusi normal.
Uji multikoliniearitas bertujuan untuk menguji ada tidaknya hubungan atau korelasi antara variabel independen yang satu dengan variabel independen yang lainnya. Hasil uji multikolinearitas menunjukkan bahwa nilai tolerance dari variabel Good government governance (GGG) yaitu 0,562 , nilai tolerance dari variabel pengendalian intern yaitu 0,609, nilai tolerance dari variabel budaya tri hita karama yaitu 0,500 adalah lebih besar dari 0,1 (10\%). Nilai VIF dari variabel Good government governance (GGG) yaitu 1779, nilai VIF dari variabel pengendalian intern yaitu 1,641 , nilai VIF dari variabel budaya Tri Hita Karana yaitu 2,001 adalah lebih kecil dari 10, sehingga dapat disimpulkan bahwa tidak terdapat gejala multikolinearitas antara variabel bebas.

Uji heteroskedastisitas bertujuan untuk menguji apakah dalam model regresi terjadi ketidaksamaan varians dari residual satu pengamatan ke pengamatan yang lain yang dilakukan dengan uji Glejser. Hasil uji heteroskedastisitas menunjukkan bahwa tingkat signifikansi semua variabel berada diatas 0,05 . Hal ini menunjukkan bahwa model regresi bebas dari masalah heteroskedastisitas.

Berikut ini hasil uji regresi linear 
berganda dapat dilihat pada Tabel 1.

Tabel 1

Hasil Regresi Linear Berganda

\begin{tabular}{|c|c|c|c|c|c|}
\hline \multirow[t]{2}{*}{ Variabel } & \multicolumn{2}{|c|}{$\begin{array}{l}\text { Unstandardized } \\
\text { Coefficients }\end{array}$} & \multirow{2}{*}{$\begin{array}{c}\text { Standardized } \\
\text { Coefficients }\end{array}$} & \multirow[t]{2}{*}{ t hitung } & \multirow[t]{2}{*}{$\begin{array}{l}\text { Sig. } \\
\text { uji t }\end{array}$} \\
\hline & B & Std. Error & & & \\
\hline (Constant) & 1,039 & 0,414 & & 2,508 & 0,014 \\
\hline $\begin{array}{l}\text { Good government } \\
\text { governance }\left(\mathrm{X}_{1}\right)\end{array}$ & 0,273 & 0,124 & 0,224 & 2,197 & 0,031 \\
\hline Pengendalian Internal $\left(\mathrm{X}_{2}\right)$ & 0,228 & 0,077 & 0,290 & 2,964 & 0,004 \\
\hline Budaya Organisasi $\left(\mathrm{X}_{3}\right)$ & 0,292 & 0,111 & 0,284 & 2,631 & 0,010 \\
\hline R Square & 0,463 & & & & \\
\hline Adjusted R Square & 0,445 & & & & \\
\hline F Statistik & 26,421 & & & & \\
\hline Signifikansi Uji F & 0,000 & & & & \\
\hline
\end{tabular}

Sumber : Data primer diolah, 2019

Berdasarkan hasil dari Tabel 1 dapat dibuat persamaan sebagai berikut.

pengendalian intern meningkat satu satuan $\mathrm{Y}=1,039+0,273 \mathrm{X}_{1}+0,228 \mathrm{X}_{2}+0,292 \mathrm{X}_{3}+\mathrm{e}$

maka kinerja organisasi perangkat daerah

Nilai konstanta 1,039 menunjukkan jika dengan asumsi variabel lainnya konstan.

variabel good government governance $\left(\mathrm{X}_{1}\right)$,

Koefisien regresi variabel budaya

pengendalian interen $\left(\mathrm{X}_{2}\right)$, budaya tri hita karana organisasi sebesar 0,292 memiliki arti

$\left(\mathrm{X}_{3}\right)$ bernilai konstan, maka variabel kinerja apabilabudaya organisasi meningkat satu satuan organisasi perangkat daerah (Y) memiliki nilai maka kinerja organisasi perangkat daerah (OPD) positif sebesar 1,039 .

Koefisien regresi good government meningkat sebesar 0,292 satuan dengan asumsi variabel lainnya konstan.

governance sebesar 0,273 memiliki arti apabila

Nilai e (Error) dalam konsep statistika

good government governance meningkat satu satuan maka tingkat kinerja organisasi perangkat daerah (OPD) meningkat sebesar 0,273 satuan dengan asumsi variabel lainnya konstan.

Koefisien regresi variabel pengendalian khususnya di dalam konsep regersilinier, error adalah semua hal yang mungkin memengaruhi variabel terikatY, yang mungkin tidak diamati oleh peneliti.

Besarnya pengaruh variabel bebas intern sebesar 0,228 memiliki arti apabila terhadap variabel terikat ditunjukkan oleh nilai 
determinasi total (R Square). Hasil uji koefisien determinasi pada Tabel 4.9 menunjukkan nilai R Square sebesar 0,463 mempunyai arti bahwa sebesar 46,3 persen variasi Kinerja organisasi pada perangkat daerah (OPD) dipengaruhi oleh variasi good government governance, pengendalian internal dan budaya organisasi, sedangkan sisanya sebesar 53,7 persen dijelaskan oleh faktor lain yang tidak dimasukkan ke dalam model.

Uji kelayakan model regresi bertujuan untuk mengetahui apakah semua variabel bebas yang diidentifikasi (good government governance, pengendalian internal dan budaya organisasi) tepat digunakan memprediksi kinerja organisasi organisasi perangkat daerah (OPD). Uji ini sering juga disebut dengan uji F. Tingkat kepercayaan yang digunakan dalam uji ini adalah 5 persen, $\alpha=0,05$. Kriteria pengujian yaitu jika nilai $F$ hitung $>F$ tabel dengan signifikansi uji $\mathrm{F}<0,05$ maka Ho ditolak dan H1 diterima, begitu pula sebaliknya.

Hasil pengolahan data pada Lampiran 9 dengan menggunakan program SPSS diperoleh nilai $\mathrm{F}$ hitung sebesar 26,421 dengan signifikansi sebesar 0,000 . Oleh karena nilai $\mathrm{F}$ hitungsebesar13,447 dengan nilai signifikansi
$0,000<0,05$, maka dapat disimpulkan bahwa pada kelompok yang diuji memiliki perbedaan yang nyata (signifikan). Hasil ini mempunyai arti bahwa secara simultan Good government governance, Pengendalian Internal dan Budaya Organisasi berpengaruh signifikan terhadap Kinerja organisasi perangkat daerah (OPD).

Pengaruh secara parsial pada variabel good government governance, pengendalian internal dan budaya organisasi terhadap kinerja organisasi perangkat daerah (OPD) diuji dengan menggunakan uji regresi linier berganda yang ditinjau berdasarkan nilai t hitung pada tabel coeffisient. Kriteria pengujian untuk menjelaskan interpretasi pengaruh antar masing-masing variabel yakni apabila nilai signifikansi $<0,05$ maka H0 ditolak dan H1 diterima. Sebaliknya, jika nilai signifikansi $>0,05$ maka H0 diterima dan H1 ditolak.

Berdasarkan hasil analisis pengaruh good government governance terhadap Kinerja Organisasi perangkat daerah (OPD) diperoleh nilai signifikasi sebesar 0,031 dengan nilai koefisien regresi positif sebesar 0,273 Nilai Signifikansi $\quad 0,031<0,05$ mengindikasikan bahwa H0 ditolak dan H1 diterima. Hasil ini mempunyai arti bahwa good government 
governance berpengaruh positif dan signifikan terhadap kinerja organisasi pada perangkat daerah (OPD).

Hasil penelitian ini sejalan dengan penelitian Fauziah (2016) menyatakan bahwa bahwa prinsip-prinsip good government governance, motivasi dan budaya organisasi berpengaruh terhadap kinerja organisasi perangkat daerah. Hasil penelitian ini mendukung teori keagenan disini memberikan pengertian bahwa pihak manajemen instansi yang berperan sebagai agen dan anggota yang sebagai prinsipal dalam agency relationship. Pengurus memperoleh wewenang dan kekuasaan dari kepala dinas untuk menjalankan tugas dan wewenang yang diberikan. Atas dasar itu pengurus merumuskan berbagai kebijaksanaan yang harus dilakukan pengelola dan menjalankan tugasnya. Pengurusyang berperan sebagai agen merupakan pihak yang memperoleh mandat dari anggota sebagai prinsipal untuk menjalankan tugas mengoptimalkan pemanfaatan sumber daya yang dimiliki oleh pemerintah.

Berdasarkan hasil analisis pengaruh pengendalian internal terhadap kinerja organisasi perangkat daerah (OPD) diperoleh nilai signifikansi sebesar 0,004 dengan nilai koefisien regresi yang positif sebesar 0,228. Nilai Signifikansi $\quad 0,004<0,050, \quad$ maka mengindikasikan bahwa $\mathrm{H} 0$ ditolak dan $\mathrm{H} 2$ diterima. Hasil ini mempunyai arti bahwa pengendalian internal berpengaruh positif dan signifikan terhadap kinerja organisasi pada perangkat daerah (OPD).

Hasil tersebut sesuai dengan hasil penelitian yang dicapai (Dharmawan \& Supriatna, 2016) yang menyatakan hasil penelitian menunjukan bahwa penerapan sistem pengendalian internal di pemerintah Kota Bandung telah terlaksana dengan sangat baik. Selain itu, pelaksanaan kinerja aparatur Pemerintah Kota Bandung juga telah sesuai dengan prinsip good governance. Hasil penelitian juga menunjukan bahwa terdapat pengaruh positif antara implementasi sistem pengendalian internal terhadap kinerja instansi pemerintah. Sehingga $\mathrm{H} 0$ ditolak dan $\mathrm{H}_{2}$ diterima.

Hasil penelitian ini mendukung teori stewardship, dimana pengendalian inten sebagai steawardyang bertugas membantu pimpinan di masing-masing instansi dalam hal pengendalian intern penting untuk memiliki pengalaman kerja yang memadai. Hal ini 
sudah terlihat dari semua Organisasi perangkat daerah (OPD) yang menjadi sampel, karena pengendalian intern tersebut rata-rata memiliki pegalaman kerja di atas 2 tahun. Semakin lama pengalaman kerja seorang pengendalian intern, maka pegawai akan lebih memahami dan menguasai suatu keterampilan dalam bidang yang ditekuninya dan dapat menghasilkan laporan hasil pengawasan dengan lebih baik, dan semakin mudah meminimalisir kesalahan dalam penyusunan laporan.

Berdasarkan hasil analisis pengaruh budaya organisasi terhadap kinerja organisasi perangkat daerah (OPD) diperoleh nilai signifikansi sebesar 0,010 dengan nilai koefisien regresi positif sebesar 0,292.Nilaisignifikansi $0,010<0,05$ mengindikasikan bahwa H0 ditolak dan $\mathrm{H} 3$ diterima. Hasil ini mempunyai arti bahwa budaya tri hita karana berpengaruh positif dan signifikan terhadap kinerja organisasi pada perangkat daerah (OPD).

Hasil penelitian ini sesuai dengan penelitian Riana dkk., (2011) yang menyatakan budaya tri hita karana mempunyai pengaruh terhadap kinerja organisasi. Demikian juga, penelitian dari Astini \& Yadnyana (2019) menyatakan budaya tri hita karana berpengaruh pada kinerja keuangan di Lembaga Perkreditan Desa Kabupaten Jembrana. Hasil penelitian ini memberikan gambaran bahwa dengan menerapkan budaya tri hita karana dapat meningkatkan kinerja organisasi perangkat daerah. Budaya tri hita karana adalah budaya yang menenerapkan nilai-nilai luhur yang meliputi menjaga keharmonisan hubungan antara manusia denga Tuhan, manusia, dan lingkungan.

\section{SIMPULAN DAN SARAN}

Berdasarkan hasil analisis data dan pembahasan di atas, maka dapat ditarik kesimpulan sebagai berikut: 1) Organisasi perangkat daerah (OPD) melakukan good government governance berpengaruh positif terhadap kinerja Pemerintah Daerah Kabupaten Karangasem. 2) Pengendalian intern di organisasi perangkat daerah (OPD) berpengaruh positif terhadap kinerja Pemerintah Daerah Kabupaten Karangasem. 3) Budaya tri hita karana di organisasi perangkat daerah (OPD) berpengaruh positif terhadap efektivitas kinerja Pemerintah Daerah Kabupaten Karangasem.

Berdasarkan hasil penelitian dan simpulan yang diperoleh serta keterbatasan 
penelitian yang ada, maka dapat dikemukakan saran-saran sebagai berikut: 1) Organisasi perangkat daerah (OPD) yang ada di Kabupaten Karangasem dimana dalam penelitian ini menggunakan sampel seluruh organisasi perangakat daerah (OPD) Kabupaten Karangasem yang berjumalah 32 diharapkan terus meningkatkan efektivitas kinerjanya di Instansinya masing-masing, karena dengan adanya good government governance yang efektif diharapkan dapat meminimalkan kecurangan-kecurangan yang mungkin timbul dalam suatu instansi seperti praktik korupsi, pengelolan pendapatan dan pengelolaan belanja yang tidak sesuai ketentuan, yang dapat menimbulkan kerugian bagi daerah tersebut. 2) Organisasi perangkat daerah (OPD) Kabupaten Karangasem diharapkan terus mengevaluasi kinerja pegawainya agar dapat memberikan pelayanan publik yang terbaik dan memuaskan masyarakat serta dapat meningkatkan kinerja instansi di Kabupaten Karangasem.

\section{REFERENSI}

Ambarwati, 2013. “Analisis Pengaruh Penerapan Prinsip-Prinsip Good Corporate Governance Dan Komitmen Organisasi Terhadap Kinerja Aparatur Pemerintahan (Studi Empiris pada Instansi-Instandi Dan Satuan Kerja Perangkat Daerah Kabupaten Banyumas)". Jurnal SNA
XV1. Universitas Jendral Soedirman.

Akuntabilitas dan Good Governance, Lembaga Administrasi Negara Dan Badan Pengawasan Keuangan Dan Pembangunan, Jakarta, 2000.

Astini, N. K. A. T., \& Yadnyana, I. K. (2019). Pengaruh Penerapan GCG dan Budaya Tri Hita Karana pada Kinerja Keuangan Lpd Di Kabupaten Jembrana. E-Jurnal Akuntansi Universitas Udayana, 27(1), 90-118. https://doi.org/https://doi. org/10.24843/EJA.2019.v27.i01.p04

Dharmawan, T., \& Supriatna, N. (2016). Pengaruh Implementasi Sistem Pengendalian Internal Terhadap Kinerja Instansi Pemerintah (Studi Kasus Pada Organisasi Perangkat Daerah Pemerintah Kota Bandung). Jurnal Riset Akuntansi \& Keuangan, 4(1), 941-948.

Fauziah, S., \& Trisnawati, R. 2016. Analisis Pengaruh Penerapan Prinsip-Prinsip Good Corporate Governance, Motivasi Dan Budaya Organisasi Terhadap Kinerja Aparatu Pemerintahan (Studi Empiris pada Satuan Kerja Perangkat Daerah Kota Surakarta). Jurnal UMS. Fakultas Ekonomi Universitas Muhammadiyah Surakarta.

Ghozali, I. (2013). Aplikasi Analisis Mutivariate Edisi Ketujuh. Semarang: Universitas Diponegoro.

Ghozali, I. (2016). Aplikasi Analisis Multivariete Dengan Program IBM SPSS 23 Edisi 8 Cetakan Ke VIII. Semarang: Universitas Diponegoro.

Komite Nasional Kebijakan Governance (KNKG). 2006. Pedoman Umum Good Corporate governance Indonesia, Jakarta.

Nurillah, A. S., \& Muid, D. (2014). Pengaruh Kompetensi Sumber Daya Manusia, Penerapan Sistem Akuntansi Keuangan Daerah(SAKD), Pemanfaatan Teknologi Informasi, Dan Sistem Pengendalian Intern Terhadap Kualitas Laporan Keuangan Pemerintah Daerah (Studi Empiris Pada SKPD Kota Depok). Diponogoro Journal of Accounting, 3(2), 1-13.

Peraturan Pemerintah, 2008. Sistem Pengendalian Intern Pemerintah. PP Nomor 60 Tahun 2008. 
Riana, I. G., Zain, D., Troena, E. A., \& Sudarma, M. (2011). Dampak Penerapan Budaya Tri Hita Karana terhadap Orientasi Kewirausahaan dan Orientasi Pasar serta Konsekuensinya pada Kinerja Usaha (Studi pada Industri Kecil Menengah Kerajinan Perak di Bali). JAM: Jurnal Aplikasi Manajemen, 9(2), 601-610.

Robbins. 2010, Prinsip-prinsip Perlaku Organisasi, Edisi Kelima. Jakarta: Erlangga

Setyawan, K. M., \& Putri, I. G. A. M. A. D. (2013). PENGARUH GOOD CORPORATE GOVERNANCE TERHADAP KINERJA KEUANGAN LEMBAGA PEKREDITAN DESA DI KECAMATAN MENGWI KABUPATEN BADUNG. E-Jurnal Akuntansi Universitas Udayana, 5(3), 586-598.

Sugandi, J., Desmiyanti, \& Hanif, R. A. (2014). Pengaruh Kapasitas Sumber Daya Manusia, Pemanfaatan Teknologi Informasi, Pengendalian Intern Akuntansi, dan Komitmen Organisasi Terhadap Keterandalan Pelaporan Keuangan Pemerintah Daerah (Survei Pada SKPD se-Kabupaten Kuansing). Jurnal Online Mahasiswa Fakultas Ekonomi, 1(1), 1-15.

Yosefrinaldi.(2013).PENGARUHKAPASITAS SUMBER DAYA MANUSIA DAN PEMANFAATAN TEKNOLOGI INFORMASI TERHADAP KUALITAS LAPORAN KEUANGAN PEMERINTAH DAERAH DENGAN VARIABEL INTERVENING SISTEM PENGENDALIAN INTERN PEMERINTAH (Studi Empiris pada Dinas Pengelolaan Keuangan dan Aset Daera. Jurnal Akuntansi, 1(1), 1-24. 